\title{
The Top 100 Questions for the Sustainable Intensification of Agriculture in India's Rainfed Drylands
}

Zareen Pervez Bharucha Global Sustainability Institute, Anglia Ruskin University. 183, East Road, Cambridge CB11PT, UK. E: zareen.bharucha@anglia.ac.uk

Simon Attwood, Bioversity International, Rome, Italy

Shrinivas Badiger, Ashoka Trust for Research in Ecology and the Environment, Bangalore, India.

Arun Balamatti, ICAR-JSS-Krishi Vigyan Kendra, Mysuru, India.

Richard Bawden, Western Sydney University, Sydney, Australia.

Jeffery W. Bentley, Access Agriculture, Cochabamba, Bolivia

Arunabha Bhattacharya, Vrutti Livelihood Resource Centre, Bengaluru, Karnataka

Mahesh Chander, Indian Council of Agricultural Research - Indian Veterinary Research Institute, Izatnagar, India.

G. Ravindra Chary, ICAR-All India Coordinated Research Project for Dryland Agriculture, Hyderabad, India

Leonora Davies, School of Life Sciences, Anglia Ruskin University, Cambridge, U.K.

Harry Dixon, Centre for Ecology and Hydrology, Wallingford, U.K.

John Dixon, Crawford School of Public Policy, The Australian National University, Canberra, Australia. Marcella D'Souza, Watershed Organisation Trust and WOTR-Centre for Resilience Studies, Pune, India. Cornelia Butler Flora, Iowa State University, Ames, Iowa, USA.

K.A. Gopinath Central Research Institute for Dryland Agriculture, Hyderabad, India.

Michael Green, Wood Plc. London, U.K.

Deepa Joshi, Centre for Agroecology, Water and Resilience, Coventry University, Ryton-on-Dunsmore, U.K.

Adam M. Komarek, International Food Policy Research Institute, Washington, DC, USA.

Lesley Ruth McDermid, (formerly) Lord Ashcroft Business School, Anglia Ruskin University, Cambridge, U.K.

Erik Mathijs, Division of Bioeconomics, Catholic University of Leuven, Leuven, Belgium.

Agnes C. Rola, College of Public Affairs and Development, University of the Philippines, Los Baños, Philippines.

Sasmita Patnaik, Council for Energy, Environment and Water, New Delhi, India.

Sandip Pattanayak, Green Foundation, Bangalore, India.

Prabhu Pingali, Tata-Cornell Institute and Charles H Dyson School of Applied Economics and Management, Cornell University, Ithaca, NY, USA.

Yvonne Pinto, Firetail, London, UK.

V P Vara Prasad, Sustainable Intensification Innovation Lab, Kansas State University, USA.

Rudy Rabbinge, Wageningen University, Wageningen, Netherlands.

G.V. Ramanjaneyulu, Centre for Sustainable Agriculture, Secunderabad, India.

N.H. Ravindranath, Indian Institute of Science, Bangalore, India.

Colin Sage, (formerly) Department of Geography, University College Cork, Cork, Ireland.

Amrita Saha, Institute of Development Studies, University of Sussex, Brighton, UK.

Ceccarelli Salvatore, Bioversity International, Rome, Italy.

Lopamudra Patnaik Saxena, Centre for Agroecology, Water and Resilience, Coventry University, Rytonon-Dunsmore, UK.

Chandni Singh, Indian Institute for Human Settlements, Bangalore, India.

Pete Smith, Institute of Biological and Environmental Sciences, University of Aberdeen, Aberdeen, UK.

Arjuna Srinidhi, Watershed Organisation Trust, Pune, India.

Rudresh Sugam, (formerly) Council for Energy, Environment and Water, New Delhi, India.

Richard Thomas, International Centre for Agricultural Research in the Dry Areas (ICARDA).

Norman Uphoff, Cornell University, Ithaca, NY, USA.

Jules Pretty, School of Life Sciences, University of Essex, UK. 


\begin{abstract}
India has the largest area of rainfed dryland agriculture in the world, with a variety of distinct types of rainfed dryland farming systems producing most of its coarse cereals, food legumes, and minor millets, and large amounts of livestock. All these are vital for national and regional food and nutritional security. Yet, the rainfed drylands have been relatively neglected in mainstream agricultural and rural development policy. As a result, significant social-ecological challenges overlap in these landscapes: endemic poverty, malnutrition and land degradation. Sustainable intensification of dryland agriculture is essential for helping to address these challenges, particularly in the context of accelerating climate change. In this paper, we present 100 questions that point to the most important knowledge gaps and research priorities. If addressed, these would facilitate and inform sustainable intensification in Indian rainfed drylands, leading to improved agricultural production and enhanced ecosystem services. The horizon scanning method used to produce these questions brought together 40 experts and practitioners involved in a broad range of disciplines and sectors. This exercise resulted in a consolidated set of questions covering the agricultural drylands, organised into 13 key themes. Together, they represent a collective programme for cross- and multi-disciplinary research on sustainable intensification in the Indian rainfed drylands.
\end{abstract}

\title{
Keywords
}

Drylands; India; Rainfed agriculture; Sustainable intensification 


\section{Introduction}

The world's drylands form an extensive biome ,covering some $45 \%$ of the terrestrial surface area (Prăvălie 2016). Some 2.5-3 billion people live and rely upon in the drylands (Mirzabaev et al. 2019). The sustainable intensification of rainfed (non-irrigated), dryland agriculture is a global priority for meeting the Sustainable Development Goals, particularly for poverty alleviation (Goal 1), food and nutritional security (Goals 2 and 3), livelihoods and economic growth (Goal 8), climate action (Goal 13), and halting and reversing land degradation conserving biodiversity and restoring land productivity (Goal 15).

Here we have synthesized the top 100 research questions addressing key knowledge gaps, as identified by scholars and practitioners for rainfed dryland agriculture in India. We have developed this using an adapted version of the Delphi method previously used to identify key questions in a number of fields within the agricultural and environmental sciences (Dey et al. 2020), including ecology and conservation (Sutherland et al. 2019a), global agriculture (Pretty et al. 2010), food systems (Ingram et al. 2013), the environmental influence of pharmaceuticals and personal care products (Boxall et al. 2012; Rudd et al. 2014), water (Brown et al. 2010) and social science and humanities contributions to energy transitions (Foulds et al. 2019).

Our aim was to catalyse the development of a new, cross- and multi-disciplinary research agenda on sustainable intensification for the Indian drylands. To do this, we brought together a diverse group of researchers and practitioners to generate and disseminate knowledge for the benefit of dryland farmers and rural people in India. Our intended audience includes academic researchers within both the natural and social sciences, and decision makers (from the public and private sectors, and from civil society) charged with formulating strategies for research funding, rural development, agricultural policy and resource management.

We first briefly describe the social-ecological challenges facing the world's drylands and Indian rainfed dryland agriculture specifically, and then turn to the concept of sustainable intensification. We then describe the methods used to formulate the Top 100 questions. These are classified into four sections and 13 themes, representing different stages of the agricultural value chain and a variety of key focus areas. We conclude the paper with reflections on the process and discuss some of the challenges involved in implementing sustainable intensification at scale. 


\section{The drylands}

Definitions of drylands vary, but mainly centre on relative water availability, which constrains biological productivity. The most common definition is related to aridity, and relies on the ratio between evaporation and evapotranspiration, where a ratio $<0.65$ currently defines a region as a dryland (Sörensen 2007). Drylands range from hyper-arid, arid, semi-arid or dry sub-humid, with an increasing gradient of primary productivity as the ratio increases. Yet, aridity alone does not fully capture the considerable social-ecological diversity of drylands, and inappropriately makes water availability the core driver of vulnerability. This eclipses many of the economic and political drivers of vulnerability in the drylands (Geist and Lambin 2004; Reynolds et al. 2007; Sietz 2011; Sietz et al. 2017).

The drylands are significant for sustainable development globally. Around 70\% are located in Asia and Africa (Mirzabaev et al. 2019), and it is within these regions that the largest relative growth in population is expected by 2050 (van der Ensch et al. 2017). Around a quarter of dryland agriculture is rainfed (D'Odorico et al. 2013) depending on seasonal precipitation, sometimes supplemented by intricate water storage and sharing arrangements, achieving some degree of protective irrigation (Krätli 2015). In these landscapes, neither aridity nor dependence on seasonal monsoon rainfall has historically been an absolute barrier to land-based livelihoods.

Whilst rainfed dryland systems have, historically, demonstrated great resilience to water variability, they are now vulnerable to the combined pressures of land degradation, climate change and rising food demands imposed by growing and increasingly affluent populations (Mirzabaev et al. 2019). Key to sustainable livelihoods in the drylands is the need to mitigate land degradation, expressed as a combination of soil erosion, reduced plant productivity and reduced groundwater levels. Land degradation is concentrated in areas that contain $20 \%$ of the global dryland population (Klein Goldewijk et al. 2017).

India has the greatest prevalence of rainfed agriculture worldwide, measured both by area and value of production (Rao et al. 2015). A significant portion of rainfed systems lie in arid, semi-arid and dry sub-humid zones, with some $90 \%$ of India's croplands lying in the 'water limited' tropics (Milesi et al. 2010). Around $80 \%$ of India's rainfed farmers cultivate less than 1 ha of land; some $30 \%$ of the population in degraded semi-arid watersheds live below the poverty line (Ryan and Spencer 2001). The total extent of degraded land is 75.5-103 $\mathrm{M}$ ha, with most of this found in semi-arid and arid areas (Ravindra 2007). 
The Indian drylands have diverse climate, resource, production and livelihood patterns, and wide ranges of infrastructure, institutions and policy settings differing across systems. For the purposes of this paper, some key characteristics of dryland farming systems are: Rainfed Mixed (characterized by cereals, legumes, fodder crops, livestock, off-farm activities); Dry Rainfed (coarse cereals, irrigated cereals, legumes, off-farm activities); Pastoral (livestock, irrigated cropping, migration); and Sparse (arid) (livestock where seasonal moisture permits). The Rainfed Mixed Farming System is the most important of these farming systems, covering 147 Mha and containing between one-quarter and onethird of India's agricultural population.

A focus on access to irrigation has ancient origins in the drylands of India, and continues to be important. In part, this is currently driven by a widespread emphasis on 'natural' water scarcity in the drylands (Batchelor et al., 2003; Mehta 2001; 2005; Mehta (ed.) 2010; Bharucha 2019). From the mid-1980s, a series of decentralised soil and water conservation programmes seemed to provide a promising avenue to building sustainable livelihoods in dryland watersheds. These programmes aimed to reverse land degradation, through boosting groundwater levels, improving soil structure and soil fertility, and enabling collective management by farmers of revitalised watersheds.

Some projects, particularly those run on grassroots initiatives such as in the villages of Ralegaon Siddhi and Hivre Bazar, have been remarkably successful. But more generally, gains have been patchy, partial and short-lived. In some circumstances farmers benefiting from watershed development projects have become over-extractors, depleting groundwater faster than it is recharged (Samuel et al. 2007; Bharucha et al. 2014; Singh 2018). More recently, watershed development programmes have been reimagined as instruments to strengthen local livelihoods and build capacity to adapt to climate change (Singh 2018; Chaudhari and Mishra 2016; Gray and Srinidhi 2013).

The sustainable intensification of rainfed dryland agriculture is thus about more than the provision of irrigation and needs to critically engage with changing agrarian livelihoods, dynamic natural resource bases, and changing rural aspirations that collectively mediate dryland agriculture (Agrawal and Agarwal 2017; Singh et al. 2019). It has been estimated that between 40-50\% of India's net sown area would be rainfed even if the country's irrigation potential were completely met (Rao et al. 2015). Yet, current agricultural scholarship fails to engage with the complex particularities of Indian dryland agriculture (Raina 2006).

Our Top 100 Questions exercise thus goes beyond water (though the largest theme of questions remains centred around climate, water and dryland watersheds), touching on every aspect of the 
agricultural value chain, with a view to reorienting agricultural research and practice towards the rainfed drylands.

\section{Sustainable intensification}

The term 'sustainable intensification' (SI) was first proposed to explore the potential for synergies between agriculture and natural capital (Pretty 1997). It went on to be more broadly described as raising yields without additional land conversion, and without causing environmental harm (Baulcombe et al. 2009; Cassman and Grassini 2020). Evidence shows that the use of various forms of sustainable intensification is spreading to more farmers across the world (Baulcombe et al. 2009; Pretty et al. 2011, 2018; Pretty and Bharucha 2014; 2018), with particularly strong evidence for successful application on smallholder farms in the Global South (Pretty et al. 2011; Pretty and Bharucha 2014).

Approaches to sustainable intensification vary (Weltin et al. 2018), with specific interventions ranging from crop varietal improvements, new rotations, water conservation, the system of crop intensification (SCI), integrated pest management (IPM), agroforestry, conservation agriculture (CA), crop diversification (e.g. rotations, intercropping, water harvesting) and the intensification of small patches (Pretty and Bharucha 2014; Pretty and Bharucha 2018). These practices have extended ambitions beyond simultaneously increasing agricultural productivity with less environmental impact, and towards an agenda of radical ecosystem restoration, community regeneration and socialecological resilience.

Evidence from across sub-Saharan Africa highlights the potential of these approaches for sustainable intensification in dryland systems. Examining outcomes from 40 projects and programmes in 20 countries, Pretty et al. (2011) highlighted the beneficial impacts for some 10.4 M farmers and their households, including over a doubling of crop yields, and improvements on around $12.75 \mathrm{M}$ ha, with much of this improvement achieved with locally available resources. At the same time, there have been calls for SI to expand its scope beyond crop and animal production, adopting practices across the entire value chain" (Rockström et al. 2017).

\section{Horizon Scanning}

Horizon scanning is a foresight method used to develop a collective view of future directions in a research field, identify emerging threats or opportunities, or set priorities for research or policy development. It may also be used to identify and scrutinise potential future opportunities and threats, with the aim of increasing preparedness, allowing hazards to be mitigated, and facilitating seizing 
opportunities. By focusing attention on emerging issues that may not be widely known, the process aspires to catalyse research and proactive adjustment of policies.

Horizon scanning methods vary widely depending on the aims of the exercise, but there has been a gradual standardisation and improvement over the last decade (Sutherland et al. 2011, 2019 a; b). We used a modified version of the Delphi technique that has previously been used to identify issues of greatest importance for global ecology and conservation (Sutherland et al. 2019a; b).

The Delphi technique broadly consists of a process wherein experts pool knowledge and build consensus through an iterative process. Scans have both an informative as well as a creative function: they can alert decision makers to emerging issues, as well as synthesize available knowledge and expert perspectives to provide new options for policy or practice (Amanatidou et al. 2012; Hines et al. 2019).

A focus on policymakers and strategic decision-making is central to horizon scanning practice, but audiences for horizon scans go beyond policymakers. Sutherland et al. (2011) suggest three groups of audiences for horizon scanning exercises: (i) policymakers and practitioners from public, private and third sectors; (ii) funders who may support themes that stakeholders have deemed important and (iii) researchers who may increase their attention to high priority questions.

A key consideration informing our scan has been the relative neglect of rainfed dryland agriculture across the spectrum of agricultural research in India. Existing efforts in rainfed dryland systems have focussed on crop variety development, expanding the supply of irrigation water and community based natural resource management - chiefly executed through state-run water harvesting projects. There thus remains a great deal of scope for identifying priorities that address the whole agricultural value chain. In making a beginning towards identifying these, we seek to highlight the potential for a far more comprehensive - and cross-disciplinary - research agenda on rainfed dryland agriculture in India.

To achieve this, the lead authors identified a multidisciplinary team of experts and senior representatives from key agricultural and academic organisations based both in India and internationally. Selection was purposive (Sutherland et al. 2018), aiming for a mix of subject expertise and representing a variety of issues across agricultural value chains. We also aimed for a mix of disciplinary and sectorial affiliations, seeking a balance between academic researchers and those with experience of engagement in agricultural policy or practice. Invitations to co-authors consisted of an outline of the proposed procedure and a template email to forward on to potential contributors in individuals' networks. The list of co-authors provides full information and details of participating 
individuals and their host institutions. Once co-authors confirmed their participation, the final list of questions was developed and finalised through the following three stages.

In the first stage, co-authors canvassed their professional networks with requests for contributions of suggested priority questions. The instruction given was to solicit research questions that, if answered, would contribute to the sustainable intensification of rainfed dryland agriculture in India. Co-authors were all also invited to suggest colleagues who might participate as additional co-authors or as contributors. This canvassing was undertaken mainly via email. A few co-authors made use of internal organisation social networks such as Yammer or personal network pages. Following Sutherland et al. (2011) and Pretty et al. (2010), we emphasized the following broad principles for the framing of questions:

i. Phrasing questions as open (e.g. what, when, where, who, why, how, format) rather than closed (leading to yes or no answers);

ii. Questions that should contribute to the policy or practice of sustainable intensification or improve the policy environment for sustainable intensification;

iii. Questions capable of being answered by a research team through a realistic research design and through testable hypotheses where applicable (Pullin et al. 2009);

iv. Questions capable of a factual answer and not dependant on value judgements;

v. Questions that are impact and intervention related with a subject, an intervention, and a likely measurable outcome.

A total of 366 questions were generated, and then compiled into an anonymised list, so that no information about individual proposers was available to the co-author team during the sorting and categorising stages (Pretty et al. 2010). The submitted questions were lightly edited for clarity by the lead authors, and then sorted into the following thematic categories, following Pretty et al. (2010): (i) Biodiversity, Ecosystem Services and Conservation, and Pests and Disease Management; (ii) Climate, Watersheds, Water Resources and Aquatic Ecosystems; (iii) Consumption Patterns and Health; (iv) Crop Genetic Improvement; (v) Development and Livelihoods; (vi) Energy, Climate Change and Resilience; (vii) Food Supply Chains; (viii) Governance, Economic Investment, Power and Policy Making; (ix) Human Capital; (x) Livestock; (xi) Prices, Markets and Trade; (xii) Production Systems and Technologies; (xiii) Soil Nutrition, Erosion and Use of Fertilizer. The number of questions per theme varied markedly, ranging from three questions in the theme on food supply chains, to 73 questions on 'climate, watersheds, water resources and aquatic systems' (Table 1).

Inevitably, themes had degrees of overlap, with some questions potentially suitable for more than one theme. In this case, the final allocation of questions to themes was decided by the lead authors; all co- 
Sustainable Intensification in India's rainfed drylands.

R1. August 2020

authors were invited to consider the final list and comment on the wording or allocation of questions across themes. 
Table 1: Number of questions submitted for each theme

\begin{tabular}{lc}
\hline $\begin{array}{l}\text { Climate, watersheds, water resources and aquatic } \\
\text { systems }\end{array}$ & 73 \\
\hline Soil nutrition, erosion and use of fertilizer & 25 \\
\hline $\begin{array}{l}\text { Biodiversity, ecosystem services and conservation, and } \\
\text { pest and disease management }\end{array}$ & 12 \\
\hline Energy, climate change and resilience & 4 \\
\hline Production systems and technologies & 59 \\
\hline Crop genetic improvements & 5 \\
\hline Livestock & 12 \\
\hline Human capital & 50 \\
\hline Development and livelihoods & 31 \\
\hline Governance, economic investment, power, and policy- & 66 \\
\hline making & 3 \\
\hline Food supply chains & 12 \\
\hline Prices, markets, and trade & 14 \\
\hline Consumption patterns and health & 366 \\
\hline
\end{tabular}

At the next stage, the co-author team was divided into groups of 3-6 members, based on their expertise in each of the above thematic categories. Groups were sent the list of questions categorised according to their respective thematic area as well as the full, uncategorised list of 366 questions. Each group member was given a maximum of 30 votes for each list of questions; these could be allocated as they wished against the list of questions in their theme. At this stage, group members worked individually, allocating votes to rank questions within their groups without deliberation.

When this stage was completed, one coordinator per group was assigned, responsible for facilitating discussion towards the final selection of questions for each group. The task of each group was to collectively review all the submitted and ranked questions. These were displayed in descending weighted order, including all voted and unvoted questions in each group. Groups were invited to revise, rework and reword the questions where necessary. They were also invited to add new questions where gaps in the existing themed questions were identified. The final list of 100 questions maintains the original proportions of questions submitted per theme, with theme coordinators given an approximate target for the final number of questions to be included in their group. The final list of questions was then inserted into a draft paper and sent back to all co-authors for a final check.

\section{The Top 100 Questions}

Following Pretty et al. (2010), we organised the final group of the Top 100 Questions into four sections to represent key stages in agricultural production systems: (1) natural resource inputs; (2) 
crop and livestock production; (3) agricultural development and policy and (4) markets and consumption. Questions are neither ranked in order of priority, nor in order of numbers of votes received.

\section{Section 1: Natural Resource Inputs}

\section{i. Climate, watersheds, water resources and aquatic ecosystems}

Indian agriculture is highly dependent on the seasonal southwest monsoon, which brings around $80 \%$ of the subcontinent's rainfall over a four-month period from June to September (Kumar et al. 2010). The main kharif crop sowing season coincides with this monsoon period, on which rainfed farming fundamentally depends. Climate change is projected greatly to increase monsoon variability, as well as increasing the risks of pest and disease incidence, distribution of run-off, soil moisture regimes, groundwater regimes and flood and drought risk (Jha et al. 2019).

Inland aquatic systems are also likely to be significantly affected, although the responses of these ecosystems to climate change are still poorly understood (Patel et al. undated). The impacts on productivity and livelihoods of changes in climate differs across the farming systems, from most severe for rainfed cropping in the Rainfed Mixed Farming System, to significant in the Pastoral and Sparse (arid) livestock range grazing systems to least in the Dry Rainfed System on the Deccan with significant irrigated cropping.

In addition to climate change, Indian water resources continue to be impacted by factors associated with population growth and socioeconomic development. Changing land-uses impact upon runoff regimes, while longstanding over-abstraction and competition for water between sectors places pressures on the available resource. Per capita freshwater availability in India is currently $1545 \mathrm{~m}^{3}$ per year, a fall from $5000 \mathrm{~m}^{3}$ per-capita per year at Indian independence in 1947.

Technologies to improve water management and irrigation efficiency have produced mixed outcomes. In Rajasthan, subsidies for drip irrigation have increased the irrigated area and the total volume of water applied by farmers (Birkenholtz 2017). Groundwater irrigation has replaced many surface water sources across India (Shanker et al. 2011). Landowners are currently given full rights to install wells and abstract water freely under their own land, and most groundwater extraction continues to be controlled by individual landowners (Cullet 2014). Further south in the peninsular drylands, watershed development projects meant to rejuvenate degraded catchments areas have, over time, resulted in an increase in water extraction, mostly through a proliferation of well-digging on individual farms (Bouma et al. 2007; Samuel et al. 2007; Bharucha et al. 2014; Singh et al 2018; Solomon and Rao 2018). 
While understanding of India's hydrology and water resources management has increased significantly, the complex interactions and feedbacks between different components of the system present unresolved questions. The ability to monitor, model and predict hydrological variability at different scales remains incomplete. If addressed, these questions would enable development of improved hydroclimatic services. A particular priority will be ensuring that these are co-produced with all stakeholders, most especially dryland smallholders (Bharucha et al. 2018).

1. What is needed to predict and communicate future hydrological conditions over seasonal timescales to inform effective crop planning and management and how can short-term realtime hydrological and weather forecasting be improved to support farmers during critical periods (e.g. sowing, flowering, maturity)?

2. What efforts and initiatives will help offset the impacts of drought particularly to high-risk, low-capacity small farmers?

3. What are the best strategies for improving water storage and aquifer recharge in the context of recent overuse of groundwater abstraction?

4. What are the best farm-based and non-farm livelihood options for small dryland farmers to increase farmers' income while also increasing climate resilience?

5. What factors are driving the transition from agro-climatically appropriate crops to waterintensive commercial crops in the drylands?

6. What factors are limiting the adoption of new technologies to improve water-use efficiency and best irrigation management practices?

7. How do large-scale, human-induced catchment changes (including alterations to crop types and land management practices) alter local and regional hydrological systems?

8. How will the impacts of hydro-climatic changes over the past fifty years in dryland agriculture be shaped by the emerging challenges of climate change?

9. What will be the critical trade-offs in agricultural intensification (e.g. technologies, markets) where shortages of groundwater and soil moisture are experienced?

10. How can the sustainable intensification of rainfed dryland agriculture be aligned with greenhouse gas reduction targets and the building of climate resilience?

11. How can agro-ecological and socio-economic datasets be used effectively to assess and monitor practices, as well as identify knowledge gaps, to prioritise options for the future of dryland agriculture?

12. What are the best location-specific adaptation measures and practices to manage climate change in drylands agriculture and how can such measures be economically identified in a timely fashion?

13. What are the most effective water demand management strategies and how can these be operationalised, to simultaneously improve water supply?

14. How can improved monitoring of soil moisture and crop water demand be combined with more efficient methods of irrigation and increased wastewater reuse to help meet India's growing agricultural water demands?

15. What are the climatic thresholds beyond which watershed management and other adaptation practices are no longer effective in dealing with increasing frequency of extreme events (e.g. droughts, floods)?

16. How can soil and landscape management methods be appropriately incorporated into planning for sustainable agricultural practices? 
17. How can improved sustainable and intensified cropping systems be developed that will allow farmers to better manage climate variability whilst also increasing net productivity?

18. How can communication of current understanding of water balance studies in different ecosystems be improved to support farmers in their planning of rainfed agricultural practices?

19. How can local small-scale water management be improved to provide supplementary irrigation without creating detrimental downstream impacts on water resources?

20. What are the best strategies for redesigning sustainable agricultural development that goes beyond just crop productivity enhancement?

\section{ii. Soil nutrition, erosion and use of fertilizer}

Predominant soil types in the Indian dryland are alfisols and vertisols in the peninsular regions and aridisols and entisols in the arid regions (Rao 2011). These soils are relatively coarse, with high sand content, and limited nutrient and water-retaining capacity (Srinivasa et al. 2015), representing a significant constraint on crop productivity. In India, on-farm studies of soil fertility status have traditionally focussed on irrigated systems with less effort on rainfed systems. When these are tested, they show deficiencies in a number of micronutrients (Rego et al. 2007). Soil organic matter is also low across the rainfed drylands, as a result of prevailing agroclimatic conditions, erosion of topsoil (Srinivasa Rao et al., 2009; Rao 2011), declining availability of cattle manure (Indoria et al. 2018), and poor rate of return of vegetative biomass to soil via mulch or compost.

A depletion of soil organic carbon stocks are a key concern because carbon improves soil structure to help retain nutrients and moisture. Improved soil management would sequester significant amounts of carbon (Srinivasa Rao et al. 2009), yet recent agricultural practices have contributed to a depletion of soil organic carbon. Some of these practices include excessive tillage, use of heavy machinery for tillage and harvest, excessive or unbalanced use of mineral fertilizers, overgrazing, poor water management and poor crop cycle planning (Bhattacharyya et al. 2015).

Improving soil health in the rainfed drylands will require more than changed fertilizer regimes. Since the Green Revolution, the partial factor productivity of fertilizers has decreased from $42 \mathrm{~kg}$ grain $/ \mathrm{kg}$ NPK in 1975 to around $8 \mathrm{~kg}$ grain/kg NPK in 2010 (Indoria et al. 2018), in part due to continued deterioration in the physical, chemical and biological health of soils (Rao 2011). Alternatives to cattle manure include tank silt, crop residues and husks, green manures, poultry manure, agro-processing waste (such as from sugarcane, tea, jute, groundnut, sericulture, and fruit processing), biochar, vermicompost, and municipal biosolids (Indoria et al. 2018). However, competing uses for some of these alternatives mean they are often not used as soil amendments. For example, crop residues can be retained in the field as a mulch to increase soil nitrogen content and reduce evapotranspiration but 
then the residues cannot be used to feed livestock or used as a cooking or heating fuel (Valbuena et al. 2012).

21. What will be the best nutrient cycling and management practices for sustainable intensification of crop-livestock systems in the Indian drylands?

22. How can soil carbon be increased under dryland conditions, and what trade-offs might ensue if increasing soil carbon results in greater immobilization of nutrients such as nitrogen?

23. How can social capital be improved to ensure better collective use of water in the drylands and better use of communally owned lands to provide biomass to arable areas?

24. Which crop management practices are best fits to the biophysical and socio-economic constraints of the drylands?

25. What factors are limiting the adoption of better crop management practices (such as pulse crops after rice) at the different scales of farms, households and communities?

26. Which soil and perennial crop management (including agroforestry) practices can increase production whilst preventing and reversing land degradation?

27. What are the priority management practices for improving soil health in drylands?

\section{iii. Biodiversity, ecosystem services and conservation, and pest and disease management}

Globally, drylands are home to $17 \%$ of the centres of plant diversity, 60 endemic bird areas, and 1300 protected areas (White and Nackoney 2003). Mainstream development policy and practice has tended to neglect the importance of biodiversity conservation as a development issue, and few commentators have discussed the tradeoffs and synergies between biodiversity conservation and sustainable land management in India (but see Amjath-Babu and Kaechele 2015), who find a "reduction in farming system diversity, increase of cultivation intensity, reflecting a reduction in planned and associated agrobiodiversity" across India.

In an early commentary on watershed development projects in semi-arid India, Batchelor et al. (2003) highlighted how village-level watershed planning tends to ignore biodiversity and habitat conservation, and the need for more explicit financial support for this. Conventional agricultural intensification is a globally significant driver of ecosystem degradation, habitat loss and biodiversity loss even without the conversion of non-agricultural land.

So far, little attention has been paid to this within Indian rainfed drylands (but see Kumar and Srivastava 2018; Dutta and Jhala 2014). Where this issue has been studied, it has been shown that conventional intensification is likely to have a deleterious effect on species of conservation concern, but increasing rotational land use and habitat heterogeneity and integrating community conservation reserves into the production matrix could have positive biodiversity outcomes (Dutta and Jhala 2014).

On Indian dryland farms, weeds compete for scarce water and nutrients, and cause between $10 \%$ and 98\% of crop losses or total crop failure (Ramamoorthy et al. 2004). Some weeds also hamper the quality of produce, and act as host plants for a variety of additional pests and diseases (Rao et al. 
2018). On the other hand, flowering weeds also provide shelter and nectar that parasitic wasps and other beneficial insects need for the biological control of insect pests.

28. How can the predominant models of 'modern' (input-dependent) agricultural development that tend to reduce agrobiodiversity be reversed in favour of more agroecologically-based models, so as to increase both biodiversity and resilience sustainably?

29. How does land-use change across the rainfed drylands impact off-farm biodiversity and what synergies are possible between agricultural intensification and biodiversity conservation?

30. What ecosystem services need to be conserved and stewarded in order to meet interlinked goals of income generation, farm resilience, and livelihood resilience across the dryland agroecosystems of India?

\section{iv. Energy, climate change and resilience}

Energy use in agriculture consists of direct use in machinery and energy consumption indirectly embedded within products (Scheider and Smith 2009). In rainfed drylands, farmers depend heavily on subsidized electricity to run tubewell pumps, and there are thus important intersections between the availability of energy, water, and livelihood security (Mukherjee 2017), best viewed in the context of Food-Energy-Water security (FAO 2014).

Notably, food production depends on both energy and water, which are interdependent. Water scarcity can be exacerbated by electricity shortages (Chhotray 2011), and with falling groundwater levels, deeper tubewells necessitate electric (rather than diesel-run) pumps (Singh 2019). The spread of electric pumps has often led farmers to need to shift to water-intensive, high-value crops in order to cover costs (Bouma and Scot 2006).

Furthermore, electricity supply is often erratic, and this has important implications for efficient water use and general resilience. For example, farmers in Maharashtra's Ahmednagar district report having to go to their fields in the middle of the night to supply irrigation water whenever electricity becomes available and report being unable to gauge how much water is being applied when irrigation is carried out in the dark (Bharucha 2011).

However, many States are now initiating implementation of the 'Gujarat model' of separate lines for domestic and agricultural power. Where efforts are being made to supply farmers with renewable sources - particularly solar-powered pumps (Kumar et al. 2015), questions remain as to whether this will, again, worsen the over-extraction in already stressed aquifers. In relation to rainfed cropping, there are opportunities for substantial savings in energy through conversion from tradition tillage ground preparation to non-till conservation agriculture based sustainable intensification (CASI) which eliminates ploughing by oxen or tractor. 
31. What are the benefits and trade-offs generated by improved mechanisation on different types of rainfed farm?

32. What are entry and structural barriers to improved mechanisation for the most marginalised of stakeholders, including women, the latter, given reported trends of male out migration and a feminisation of agriculture in India?

\section{Section 2: Crop and livestock production}

\section{v. Production systems and technologies}

A variety of production systems have been shown to improve yields while improving ecosystem services and revitalising farming communities (Dixon et al. 2001; IAASTD 2009; Pretty et al. 2011; Bharucha and Pretty 2014; Pretty and Bharucha 2018). These show that while there is no 'silver bullet' for sustainable intensification that works for all production systems, agroecologically-based interventions can generate remarkable improvements over a wide variety of contexts, particularly if suitably targeted to the characteristics and needs of particular farming systems.

These production systems include initiatives such as agroforestry, the system of crop intensification, conservation agriculture, the intensification of small patches such as field margins and home-gardens, new crop-livestock or crop-fish systems, and integrated pest management. Many of these systems have been taken up at scale in dryland smallholder farms, particularly across sub-Saharan Africa (Pretty et al. 2011) and more recently in pockets of success in the Indian drylands, often facilitated by community groups and NGOs.

In Indian rainfed drylands in the decades following the Green Revolution, a number of alternative production systems have been implemented at varying scales - from small-scale exemplars to statewide initiatives - in the decades following the Green Revolution. The dryland states of Karnataka, Andhra Pradesh, Madhya Pradesh, Tamil Nadu, Maharashtra and Gujarat have policies or laws supporting organic agriculture, and India as a whole has an estimated1,149,371 organic producers (Willer et al. 2020). In Andhra Pradesh, an ambitious policy aims to roll out the agroecological package of Community-Managed (formerly Zero Budget) Natural Farming (CMNF) to all 6 million of the state's farmers by mid 2020s (UNEP 2018). The System of Crop Intensification (SCI) is being applied across a number of crops, including finger millet, wheat, maize, sugarcane, mustard, a variety of pulses, vegetables, horticultural and spice crops, including via state and central government interventions (Adhikari et al. 2018). There have also been efforts to refine existing agroecological methods to suit the particularities of semi-arid and arid agroecosystems. The Central Arid Zone 
Research Institute (CAZRI) has, for example, developed agroforestry systems to stabilise sand dunes, wherein crops are inter-planted with a combination of Acacia spp. (Kavia and Harsh 1993).

Ultimately, investigating and scaling production system improvements for the drylands will be most cost-effectively done by participatory farming systems research and development approaches, bearing in mind the degree of integration of agroforestry-livestock systems in the drylands and the knowledge-intensiveness of appropriate innovations and system changes in the drylands.

33. What have been the key drivers of landscape and livelihood diversification in different dryland farming systems?

34. What institutional and incentive mechanisms can be used to create awareness and increase uptake among the resource poor farmers for integration of additional system components on rainfed dryland farms, especially high-value woody components (fruit trees, medicinal trees, fodder and fuelwood shrubs)?

35. To what extent do various informal seed systems contribute to the provision of quality seed for the most important dryland crops and how can these systems be improved?

36. How well-suited are currently-available varieties of major dryland crop varieties to the biotic and abiotic stresses that can be anticipated over the medium and long-term in the rainfed drylands?

37. Why have IPM and other preventative measures failed to offer scalable alternatives and what can be done to address this gap, particularly as dryland crops such as black gram, green gram and soybean are facing severe pest attacks annually?

38. What production systems and technologies related to sorghum-based systems and dairy cattlebased systems are suited for sustainable intensification given continuing land fragmentation?

39. What are the potential benefits, drawbacks and trade-offs that might be generated by new agroecosystem innovations in the rainfed drylands, including for horticulture, agroforestry, silvopasture, conservation agriculture and systems of crop intensification?

40. How can organic methods of sustainable intensification be spread to different types of rainfed farms?

41. What are long-term impacts of social capital building programmes such as participatory watershed and irrigation management on both ecosystem services and farm productivity?

42. What key lessons can be applied to the future initiatives in the drylands from social capital building programmes such as Joint Forest Management, Participatory Irrigation Management, and Farmer Field Schools?

43. What are the best ways to communicate the knowledge-intensive innovations required for the drylands to farmers of all types?

44. What farm methods are most effective in managing early- and mid-season drought and make the best use of short crop growing periods in the rainfed drylands?

45. What are the most affordable and reliable equipment, automated farm management systems and effective service providers currently in use in the rainfed drylands that could be spread to more farmers?

46. What are the most effective policy, institutional and market support mechanisms to support more adaptive farming strategies in different agroecological zones?

47. How can conservation agriculture in rainfed systems produce simultaneous benefits for food, farm incomes and soil health in the drylands? 
48. To what extent do current management approaches correspond with the intrinsic components of a comprehensive dryland management approach designed for sustainable intensification?

49. What are the biodiversity implications of current management recommendations in different dryland farming systems and how can both farm and non-farm outcomes be improved?

\section{vi. Crop genetic improvements}

From the mid- $20^{\text {th }}$ century onward, crop varietal improvement - mainly through hybridization, followed by selection - has chiefly focussed on yield and quality of key cereal crops, resulting in remarkable improvements for rice, wheat and maize. Dryland crops have received much less attention but have also benefited from some breeding programmes. Key dryland grains in India include finger millet (Eleusine coracana), pearl millet (Pennisetum glaucum), sorghum (Sorghum bicolor) and maize (Zea mays), all of which have historically shown less sensitivity to climate variability and yield declines under climate extremes than the more water-intensive crops such as rice (Oryza sativa) (Davis et al. 2019).

Varietal development for sorghum and pearl millet began in the 1960s through the All India Coordinated Crop Improvement Projects, with short-duration, high-yielding varieties having an evident impact on yields. By the early 1990s, around 55\% of the area sown to sorghum and pearl millet was planted with improved varieties, rising to around $80 \%$ in the mid-2000s; yields have since doubled (Pray and Nagarajan 2009). Yet, as with the case of improved varieties of rice and wheat (Triticum sp.) during the Green Revolution, adoption of improved dryland crops has occurred mostly on farms with relatively favourable growing conditions and in states benefitting from a relatively well-developed seed production and market infrastructure (Rai et al. 1999, in Pray and Nagarajan 2009, p. 18).

Development has continued through both private and public sector initiatives, with a focus on yields as well as disease resistance. Crop breeding for improved nutritional content is also important, given the overlap of low yields, poverty and malnutrition in the rainfed drylands. A successful example in India is the development of enriched pearl millet crops (Govinderaj et al. 2019). Key legumes include chickpea (Cicer arietinum), pigeonpea (Cajanus Cajan) and groundnut (Arachis hypogaea). These have been the focus of conventional breeding programmes initiated in the 1960s. More recently, efforts have been initiated to develop the genomic resources available for these crops (Varshney et al. 2013), opening the way for molecular breeding approaches to begin to be used.

One unusual feature of the Indian drylands is the exceptionally high straw/grain price ratio because of the strong demand for livestock feed in the Rainfed Mixed Farming System. However, in general 
there has been less progress in forage improvement for Indian conditions, except for the improvement of the dual functions of some crops such as stay-green sorghum. There has been little progress on bioenergy crops which were once seen as a panacea for the wastelands. However, some progress has been made with the selection of Acacia trees and shrubs and their management in agroforestry systems in the Sparse Arid Farming System in Rajasthan.

Overall, the most rapid successes from crop improvement were generally associated with a good understanding of the whole mixed crop-livestock farm, of risk management by farm households, and of input and produce chains. A number of institutional and regulatory measures are required in order to ensure that smallholders benefit from these improvements. These include careful attention to issues of intellectual property (Blakney 2009), the regulation of technology and engagement with farmers at every stage of crop development and seed multiplication, including during breeding.

50. What institutional changes are required to facilitate a shift in plant breeding and selection approaches to deliver more diverse and heterogeneous varieties better suited to both yield improvements and climate resilience?

\section{vii. Livestock}

The Indian drylands support $65 \%$ of the country's livestock. Nomadic and semi-nomadic pastoral communities in these landscapes rely on a number of different crop-livestock management regimes, from nomadic and semi-nomadic pastoralism in the most arid zones to agro-pastoralism and croplivestock-tree systems in the less arid zones. A rich constellation of traditional management practices has supported livestock-based livelihoods, including providing water to livestock through the use of small-scale water harvesting and storage systems such as johads (rainwater harvesting tanks) and tobas (dug ponds surrounded by dense stands of fodder grasses), reciprocal arrangements with settled farmers, the use of fallow land for grazing, and the maintenance of sacred pastures and community grazing lands.

The complexity and context-specificity of these systems necessitates a whole-farming-system approach focussing on the entire production system and taking into account traditional ecological knowledge and traditional techniques for crop and landscape management (Tanwar et al. 2018). Future threats to livestock-based systems in the drylands are likely to come from increasing climatic variability affecting livestock feed availability and the negative effects of temperature-induced heat stress on livestock productivity, progressive land degradation, conversion of traditional grazing lands and conflict with sedentary crop producers (Mirzabaev et al. 2019). 
51. What constrains the use of technologies and practices (e.g. feed mixes, appropriate breeds, pest and disease management, or smart supplements) that best increase livestock productivity and profitability while also minimising environmental concerns such as methane emissions and soil degradation?

52. To what extent are integrated crop-livestock systems more sustainable and resilient to climate and market shocks than specialized farming systems given the effects of current policies on draught power and manure availability?

53. What intensification strategies can generate synergies between using conservation agriculture in cropping systems and improving livestock productivity and profitability?

\section{Section 3: Agricultural Development and Policy} viii. Human capital

Sustainable intensification is knowledge-intensive, requiring technological and social innovation, collective learning, and the development of communities' capacity to apply this knowledge productively within their own unique contexts. Participatory development and dissemination has been key to this, including participatory varietal breeding (e.g. Assefa et al. 2011; 2013), the revitalisation of traditional knowledge, the use of 'new media' such as Information Communication Technologies and online social platforms, and collective learning from peers across landscapes. Farmer field schools and other forms of peer to peer learning (Hegde et al. 2018) have been key to the spread of a number of sustainable intensification interventions, particularly for integrated pest management (IPM), where they have been shown to improve yields and incomes (Van den Berg and Jiggins 2007; Pretty et al. 2011; FAO 2019).

In India, a key barrier to productive livelihoods has been the widespread neglect of dryland smallholders in formal skills provision, public agricultural extension and government livelihood support (Gajjar et al. 2019). Extension services remain fixed in a 'transfer of technology' mode (Sajesh and Suresh 2016), not necessarily targeting socially or economically marginalized farmers or engaging with farmer to farmer or community to community knowledge exchange and learning processes. These are also understaffed, with an estimated 100,000 extension agents in post (of the 1.31.5 million required) (Glendenning et al. 2010).

Where extension services are available, many farmers lack the opportunity to benefit, and information may be provided to farmers who are either from privileged groups or those who are easiest to reach (Cole and Fernando 2012). Partly as a result, less than 6\% of farmers report receiving information from a public extension agent in India (Glendenning et al. 2010). Yet, participatory and collective learning have shown remarkable potential, most notably within grassroots movements initiatives for soil and water conservation and within initiatives for learning new agroecological techniques. 
A notable example is the 'mega camps' bringing together thousands of farmers to learn about

Community Managed (Zero Budget) Natural Farming (Khadse et al. 2017; Khadse and Rosset 2019).

Radio and video, as well modern information and communication technonologies also have the power to reach farmers in local languages with ideas for sustainable agriculture (Bentley et al. 2019,

Chowdhury et al. 2015, Zoundji et al. 2018; Steinke et al. 2020).

54. What are the participatory approaches and methods that contribute to making sustainable intensification of agriculture targeted, appropriate and relevant to all farmers in specific geographic areas?

55. What are the essential components required to build farmers' and grassroots extension workers capacity for integrated soil management?

56. What are the key factors that facilitate collective action for resource management or agricultural transitions that is functional and sustainable over the long term?

57. How can we ensure farmer participation and ownership in exploring and implementing sustainable solutions in dryland agriculture (including farmer groups, women self-help groups, farmer producer companies)?

58. How can the social sciences help agricultural innovations and their uptake in sustainable intensification, particularly related to forms of knowledge, interaction between multiple and unequal stakeholders, social and cultural specificities that shape outcomes of different farms?

59. What are the appropriate combinations of natural resources, human resources, land use systems and enterprises in dryland agriculture that would enable improvements in both natural capital and farm income?

60. How can the challenges presented by the entry of new technologies and markets in dryland ecosystems be quickly assessed and the information quickly disseminated to the farming community and practitioners?

61. How can innovation platforms be created to improve the knowledge gaps among farmers, community-based organisations and gram panchayats to improve the development and uptake of key agricultural innovations?

62. What are the barriers to widespread adoption of SI components such as Conservation Agriculture (CA) and System for Crop Intensification (SCI) in the drylands?

63. What social, economic and cultural interactions influence adoption when dryland farmers on different types of farm are introduced to new technologies?

64. In what ways can improved communications (mobile and internet) among and between farmers and government increase resilience (e.g. through provision of climate information)?

65. How can the role of farmers and private sector-led extension services be integrated into new farming systems in dryland areas to improve profitability for farmers?

66. How can the coverage of extension and advisory services be expanded across different zones in the Indian drylands?

67. How can traditional knowledge systems be aligned with other knowledge systems in the sustainable intensification of agriculture in Indian drylands so that effective traditional practices are accepted and promoted?

\section{ix. Development and livelihoods}


Productive and resilient agricultural livelihoods are essential for mitigating multidimensional poverty and hunger in drylands. Low agricultural productivity is a key driver of this incidence. Sustainable land management can address this constraint, with positive co-benefits for income equality, poverty reduction, food security, land degradation and climate change mitigation and adaptation (Mirzabaev et al. 2019). This is increasingly vital under conditions of climate change, which is expected to disproportionately affect those already most vulnerable within communities of smallholders in the rainfed drylands.

Rural women in semi-arid regions are disproportionately vulnerable, as a result of longstanding economic and social marginalisation, lack of mobility and exclusion from decision-making (Yadav and Lal 2018). Increasing climate variability, land degradation and deepening water scarcity add substantially to women's burdens of household labour with a greater amount of time and energy to be spent in collecting water and gathering fuel. Land rehabilitation projects globally have not yet paid significant attention to this gender-differentiated aspect of land degradation, nor to women's specific knowledge and priorities for land restoration (Mirzabaev et al. 2019) or to their accessibilities and entitlements and their access to vital agricultural resources such as fertiliser (Farnworth et al. 2017).

In India, a number of initiatives mainly focused on decentralised soil and water conservation ('watershed development') have been an important effort towards crafting complementarities between land restoration and livelihood and poverty alleviation objectives (Kerr 2002; Singh 2018). Yet, there remains a gap between policy and practice. Conservation of natural resources and poverty alleviation objectives may involve trade-offs, and may prioritize high-value (and 'thirstier') crops (Bouma and Scott 2006; Ravindra 2007; Samuel et al. 2007; 2009; Daftary 2014; Bharucha et al. 2014).

68. How can the prevailing paradigm of agricultural 'productionism' that continues to dominate most research and development agendas be shifted so that development efforts are based on more inclusive thinking and practice about sustainable rural transformation on sound agroecological foundations and humanistic values?

69. How can livelihoods best be redesigned and diversified in a manner that is consistent with regenerative natural resource management practices and that pays particular attention to women's roles, burdens and benefits?

70. What are the best options to sustainably increase employment opportunities among rural youth within the broader context of alleviating rural poverty and making rural life more productive, secure, dignified, and respected?

71. How is the implementation of sustainable intensification influencing the resilience of smallholder farms and households, and how can resilience be amplified?

72. What are likely to be the most effective and feasible livelihood support initiatives under different scenarios of vulnerability and across different farm types?

73. What benefits can traditional uses of nonfarm land and indigenous knowledge systems contribute to sustainable development and livelihood development programmes? 
74. How can more and better investment in sustainable agricultural practices be encouraged with particular respect to effective linkages between scientific, technological, ecological, sociocultural, and economic components?

75. How can government development strategies, particularly in local government, be focused on achieving the desired outcomes for sustainable livelihoods in the rainfed drylands, and how can they mesh with civil society initiatives and private-sector interests and capabilities?

\section{x. Governance, economic investment, power and policy-making}

Sustainable intensification is also a governance challenge. It involves navigating between multiple (sometimes opposing), agendas, and bringing together stakeholders with vastly different interests and markedly different levels of power and political entitlement. Transitions to sustainability involve the management of risks and trade-offs, the identification of unintended outcomes, and mediating between the interests of (often powerful) incumbent actors, who may dilute, co-opt or oppose innovations that challenge their interests. Ambitious policies need to be matched by effective governance, enacted through well-functioning formal and informal institutions and supported with adequate investment.

Sustainable agriculture, in particular, depends on a broad spectrum of policy-making going beyond the immediate remit of decision-makers tasked with farming and even rural development. For example, dryland farming is greatly influenced by drought policy, which, going forward, will need to shift from a reactive mode (emphasising declaration of drought and disbursement of relief) to a proactive mode (emphasising strategies to prepare, mitigate, predict and early warning)

(Bandyopadhyay et al., 2020).

In India, a key thrust of agricultural and rural development policy has been increasing investment in irrigation. Between 1981-2014, 25\% of developmental investment was allocated to irrigation and flood control while agriculture and allied activities (including investment in rainfed agriculture, received only 19.2\% of investment (Bathla et al. 2018). Subsequent investment in soil and water conservation projects represented a bold set of policy initiatives to redress this imbalance. Policy development was iterative, representing phases of learning as outcomes failed to match initial ambitions (Singh 2018).

Further national policy development in the rainfed dryland have included attempts to marry climate action and energy policy with dryland agriculture through a National Biofuels Policy, which like watershed development policy, invokes strong 'win-win' narratives around the potential to address local development challenges while meeting broader national objectives (Pradhyan and Ruysenaar 2014). However, even synergistic policies such as farm pond schemes in Maharashtra or solar powered drip irrigation in Rajasthan involve trade-offs (Kale 2017). 
Critical scholarship on trade-offs and potentially maladaptive consequences is nascent but growing. At state level, ambitious policy making has introduced some rainfed dryland farmers to innovative and agroecologically-based practices, for example Community-Managed (Zero Budget) Natural Farming in Andhra Pradesh, a relatively unique example of state-led roll out of an agroecological package at scale (Bharucha et al. 2020).

76. How can existing inequalities and lack of access to entitlements and services be overcome in the redesign of dryland agroecosystems, with a particular focus on gender equity, unjust land rights, land fragmentation, illegal settlements and land grabbing?

77. What is the best role for financial products (such as loans and insurance packages) to increase the resilience of dryland agriculture given the stochastic nature of rainfall?

78. How can the professional interface between science and policy be strengthened to enable the sustainable intensification of rainfed dryland agriculture?

79. In what way can public-private partnerships best contribute to the sustainable intensification of dryland agriculture?

80. What policy support is necessary in order to increase the at-scale adoption of small-scale and relatively low-cost technologies such as sprinkler and drip irrigation systems and water storage technologies such as simple earthen and stone dams?

81. What curriculum changes are needed in formal agricultural universities and institutions to foster an adaptive research agenda in the context of new challenges posed by climate change and new market structures and taking into account the need for new cultures of research development, ones not dependent on 'ideal conditions' on test fields.

82. What are the priority policies for supporting a sustained regeneration of aquifers in the rainfed drylands?

83. How will the evolving politics of livestock management affect the availability of draught animals and manure amongst the poorest smallholders in rainfed dryland agroecosystems, and how can farmers maintain mixed crop-livestock agro-economies under these policy regimes?

84. What existing government programmes align with the aims of sustainable intensification and what has been their impact?

85. What is the role of public institutions of research, education, community engagement and policy enactment in fostering transformation away from narrow productionist approaches and how can public programmes be improved with direct input from multiple stakeholder groups?

86. Who are the main stakeholders involved in making decisions about agricultural investments at different scales and how can investment decisions be made more inclusive?

87. What are the most important ethical considerations that need to be incorporated into the development and spread of policies and strategies focused on the sustainable improvement of dryland agriculture in India?

88. What are the medium and long-term effects, at landscape level, of existing policy regimes governing the rainfed drylands, and how can uncertainty about second-order effects be better incorporated into policy design?

89. What policies for innovation are appropriate at different scales, given that rainfed dryland systems are characterised by high variability across space and over time?

90. Under what conditions are risk insurance policies worth considering and applying, and how do they compare with farm subsidies (e.g. $\mathrm{N}$ fertiliser)? 
91. What are the primary economic barriers to investment in new agricultural practices in the rainfed drylands, and how can the subsidy regimes be redesigned to boost production of dryland crops sustainably?

92. What could be the interests, motives and considerations behind the reluctance of the formal agricultural scientific and policy establishment in encouraging adoption of Conservation Agriculture (CA) and System of Crop Intensification (SCI) methods that are known to increase yields and reduce farm costs?

\section{Section 4: Markets and Consumption}

\section{xi. Food supply chains}

Food supply chains are all the activities that take place in food production, from on-farm to the point of consumption (Pretty et al., 2010). Efficient supply chains are key to sustainable agri-food systems, particularly within resource-constrained contexts. Across India as a whole, around $40 \%$ of agricultural produce is wasted during transportation between farm and the consumer mainly due to poor handling and storage practices, such as improper packaging and lack of cold storage (Pingali et al. 2019). Together, harvest and post-harvest food loss in India are estimated to cost US \$13 billion annually (Prakash 2018). Intensification of production thus needs to be accompanied by the development of adequate infrastructure to handle, store and transport produce.

93. How can storage capacity be enhanced to reduce post-harvest losses, including through the potential increase of private sector involvement and use of indigenous knowledge?

\section{xii. Prices, markets, and trade}

Around 52\% of agricultural households in India are indebted, with the size of average outstanding loans increasing by 3.5 times between 2002 and 2012 (Dandekar and Bhattacharya 2017). In drylands, economic policy since the Green Revolution has driven the production stagnation of millets and pulses (Kumar 2019) crops that are both suited to the physical geography of these landscapes and are nutritionally important for the most malnourished rural populations.

India is now a net importer of pulses (despite its status as the second largest producer globally) having lifted import and customs duties from the mid-2000s onward. Minimum support prices, while rising over recent years (Varma et al. 2019), remain lower than domestic prices (Varghese et al. 2019). What is needed in addition to more robust support pricing is an adequate procurement policy. For example, Varma et al. (2019) estimate public procurement for pulses "has been negligible", amounting to just 1-4\% of production between 2012 and 2015 (compared with 28-30\% for cereals). 
94. What are the most pressing challenges that farmers face as a result of existing market structures governing availability of inputs, and how could incentives need to be revised in order to support transitions to sustainable intensification?

95. What are the most equitable and effective ways to reduce the debt burden on resource-poor farmers and expand the supply of agricultural credit to those with insecure land tenure, women, and other marginalized groups?

96. What risk perceptions do input dealers have with new products and technologies, and how has this impacted wider availability and adoption?

\section{xiii. Consumption Patterns and Health}

India has a noteworthy track-record in augmenting the production of specific foods in order to meet food security goals, the application of Green Revolution technologies for cereal staples and the 'White Revolution' for milk production being key examples. Yet, there remains much to be done to ensure secure and stable access to nutritionally-important foods for much of the population, particularly in the dryland areas. Micronutrient deficiencies are common, partly due to excessive and unbalanced fertilizer use during the Green Revolution making dryland soils deficient in nutrients such as boron, copper, iron, manganese, molybdenum and zinc.

Large proportions of the Indian population consume very low levels of fruit and vegetables (Minocha et al. 2018; Choudhury et al. 2020). It is widely recognized that micronutrient deficiencies are reduced by diet diversity, which in turn is fostered in rural areas by smaller farms and diversified landscapes (Herero et al. 2017). In rural India, around $75 \%$ of young women are anaemic, half of children under five are malnourished, and over 40\% are stunted (Chava and Shah 2012; DeFries et al. 2018). At the same time, an emerging dietary transition (Rampal et al. 2018) - not restricted to urban areas (Law et al. 2020) - is leading to the emergence of type 2 diabetes and hypertension as major public health concerns (Shetty 2012).

There is a small and predominantly elite demand for fortified foods such as amaranthus, flaxseed, various indigenous millets such as ragi, kodu, etc. that is also on the one hand driving up production of these niche, nutritional crops in rural areas for consumption in urban areas. In rural drylands, aspirational shifts and personal choices are moving away from millets and towards polished rice in the South (Morisson 2016; Chera 2017) and processed wheat in the North (Kumar 2019), with critical implications for nutrition.

97. What is required to ensure agricultural policies transition away from a narrow focus on food security to a wider focus on nutrition security, addressing both under- and over-consumption of food?

98. What changes in food consumption patterns would create more market demand for crops best grown in the rainfed drylands?

99. What new opportunities and threats will emerge from changing trends in urban and rural diets, such as the rising demand for 'healthier foods' like pulses and millets? 
100. How can issues of diet and nutrition be incorporated into sustainable intensification of agriculture in the drylands, taking special account of micronutrient malnutrition and hidden hunger?

\section{Conclusions}

We have collectively generated a list of the Top 100 Questions considered by experienced scholars in the field to be key to the sustainable intensification of agriculture in the Indian rainfed drylands. These have been posed by a multidisciplinary consortium of researchers and practitioners, using a modified Delphi technique that has previously been used to identify key questions and novel, emerging threats (Sutherland et al. 2019a), including in agriculture (Pretty et al. 2010).

The questions represent knowledge gaps that need to be filled in order to ensure sustainable intensification in India's rainfed drylands and have been framed so that they are capable of being answered through a realistic research design or through the posing of testable research hypotheses. We note that there are many interdependencies between the questions and thus research approaches which are targeted to specific farming systems will be essential for effective investigation of many of the questions.

Our two main aims in undertaking this exercise have been to (i) inform future directions of research funding and policy, and (ii) directly inform the directions and priorities of individual researchers. We also hope that this exercise will encourage greater dialogue between stakeholders, so that leading experts in the field are able to inform the directions of research funding and policy, and so that policymakers are able to set strategic priorities informed by the expertise of subject experts.

A key priority in this exercise has been the need to foster multidisciplinary and cross-disciplinary knowledge creation, including posing questions answerable by researchers from across the social sciences and humanities. We anticipate that practical progress towards sustainable intensification will require new disciplinary coalitions, in which natural scientists working on new technical innovations and production systems work in effective interdisciplinary teams with social scientists and those from the humanities working on issues of management regimes as well as the values, norms and institutions which could support the redesign of agricultural systems (Hill 1985; Pretty et al., 2018).

While the questions arrived at cover a range of thematic issues, no single scanning exercise can provide a definitive guide to key priorities across social-ecological fields as complex as sustainable 
agriculture. Individual scans are deeply contingent on several factors, including the specific group of researchers involved, the networks canvassed, the agendas of individual participants and the most 'visible' or pressing priorities at the time the scanning exercise was conducted.

In order to generate as broad-ranging a list of questions as possible, we have consulted widely, canvassing initial questions from across the very extensive networks of the co-authors involved, and have specifically gone beyond scholarly academic networks to include the views of colleagues working at the interface of research and practical programmes. A key feature of question selection exercises to date has been their emphasis on consulting scholarly networks rather than canvassing questions directly from stakeholder groups (such as farmers, in this case). This is a potential avenue for further work and methodological development. We would also suggest that the questions selected are all broadly amenable to research designs crafted using a co-production approach and using participatory methodologies.

The scan was conducted over a period of three years, beginning in the summer of 2016. In reaching agreement of the final list of questions, the authors have been able to identify a relatively stable and longstanding set of knowledge gaps. These questions have thus remained relevant over a long period, and are not restricted to the most 'visible' issues at the time the scan was initially conducted. Indeed, several questions represent knowledge gaps that have remained unresolved over a period of decades. In our view, this highlights the need for greater emphasis on rainfed dryland systems within agricultural research and policy.

We also recognise that this scanning process involves difficult and imperfect trade-offs between questions. Reducing the initial list of 366 received questions to a 100 will have resulted in the loss of some questions of importance to the drylands. The final list, while reflecting broad expert consensus on the Top 100 Questions is thus very much contingent on the initial list of questions submitted, as well as the specific negotiations made within groups on which questions to keep or discard. Within our body of questions, some emerging knowledge frontiers, such as the role of soil microbiomes, and some longstanding concerns, such as salinization and nutrient pollution of groundwater sources, are thus not included.

Editing our questions for clarity and framing the questions so that they are amenable to research programmes involves reducing some of the complexity of the underlying issues. We have attempted to minimize the danger of producing a generic list of questions by avoiding ranking the final list. We also acknowledge that the questions listed here are framed as applicable to rainfed drylands as a 
whole. Yet, these landscapes are clearly not homogenous, with some 16 different types of rainfed dryland farming systems distinguished across India and communities living in these areas being differentiated by gender, caste, capacities, and aspirations. Farmers across these systems will have different priorities, access to entitlements and work within different social-ecological constraints. Women, minority communities and other vulnerable groups will also have unique priorities and constraints. We have not specifically accounted for this variability within the process of generating questions, but we anticipate that answering these research questions will involve due recognition of the heterogeneity of dryland landscapes and communities across India.

Funding details: There are no funding sources associated with this research.

\section{Acknowledgements:}

We extend grateful thanks to all the colleagues who have responded thoughtfully to our call for questions and canvassed their professional networks to ensure input from a wide range of stakeholders. The lead author extends thanks to Anglia Ruskin University for supporting two Undergraduate placements, providing essential research assistance for the project. 


\section{References}

1. Adhikari, P., Araya, H., Aruna, G., Balamatti, A., Banerjee, S., Baskaran, P., Barah, B.C., Behera, D., Berhe, T., Boruah, P. and Dhar, S., 2018. System of crop intensification for more productive, resourceconserving, climate-resilient, and sustainable agriculture: Experience with diverse crops in varying agroecologies. International journal of agricultural sustainability, 16(1), pp.1-28.

2. Agarwal, B., Agrawal, A., 2017. Do farmers really like farming? Indian farmers in transition. Oxf. Dev. Stud, 1-19.

3. Amanatidou et al. 2012. On concepts and methods in horizon scanning: Lessons from initiating policy dialogues on emerging issues. Science and Public Policy, 39, pp. 208-221.

4. Amjath-Babu, T. S., and Kaechele, H. 2015. Agricultural system transitions in selected Indian states: What do the related indicators say about the underlying biodiversity changes and economic tradeoffs? Ecological Indicators, 57, 171-181.

5. Assefa, K., Aliye, S., Belay, G., Metaferia, G., Tefera, H. and Sorrells, M.E., 2011. Quncho: the first popular tef variety in Ethiopia. International Journal of Agricultural Sustainability, 9(1), pp.25-34.

6. Assefa, T., Sperling L, Dagne B., Argaw W., Tessema D. and Beebe S. 2013. Participatory plant breeding with traders and farmers for white pea bean in Ethiopia. Journal of Agricultural Education and Extension, 20, pp. 497-512.

7. Bandyopadhyay N., Bhuiyan C. and Saha A.K. 2020. Drought mitigation: Critical analysis and proposal for a new drought policy with special reference to Gujarat (India). Progress in Disaster Science, 5, 100049.

8. Batchelor, C.H., Rama Mohan Rao, M.S. and Manohar Rao, S. 2003. Watershed development: A solution to water shortages in semi-arid India or part of the problem? Land Use and Water Resources Research 3(2003), pp.1-10.

9. Bathla S., Kumar A. and Joshi P.K. 2018. Regional income inequalities and public investments in rural India. Agricultural Economics Research Review, 31(1), pp. 13-27.

10. Baulcombe, D., Crute, I., Davies, B., Dunwell, J., Gale, M., Jones, J., Pretty, J., Sutherland, W. and Toulmin, C., 2009. Reaping the benefits: science and the sustainable intensification of global agriculture. The Royal Society.

11. Bentley, J.W., Van Mele, P., Barres, N.F., Okry, F. and Wanvoeke, J., 2019. Smallholders download and share videos from the Internet to learn about sustainable agriculture. International journal of agricultural sustainability, 17(1), pp.92-107.

12. Bharucha, Z. 2011. Local Perceptions on the Long-Term Impacts of Watershed Development Projects: Parner Taluka, Maharashtra, India. PhD thesis. University of Essex.

13. Bharucha, Z.P., 2019. This is what Nature has become: Tracing climate and water narratives in India's rainfed drylands. Geoforum, 101, pp.285-293.

14. Bharucha, Z.P., Mitjans, S.B. and Pretty, J., 2020. Towards redesign at scale through zero budget natural farming in Andhra Pradesh, India. International Journal of Agricultural Sustainability, pp.1-20.

15. Bharucha, Z.P., Smith, D. and Pretty, J., 2014. All paths lead to rain: explaining why watershed development in India does not alleviate the experience of water scarcity. The Journal of Development Studies, 50(9), pp.1209-1225.

16. Bharucha, Z.P., Sosa M., Bhave A., Chattopadhyay R., Green M., and Krishnaswamy J. 2018. Stakeholder engagement in hydro-climatic services in India. Brief 06 India-UK Water Centre (28pp.) Wallingford, UK and Pune, India.

17. Bhattacharyya, R., Ghosh, B.N., Mishra, P.K., Mandal, B., Rao, C.S., Sarkar, D., Das, K., Anil, K.S., Lalitha, M., Hati, K.M. and Franzluebbers, A.J., 2015. Soil degradation in India: Challenges and potential solutions. Sustainability, 7(4), pp.3528-3570.

18. Birkenholtz, T., 2009. Irrigated landscapes, produced scarcity, and adaptive social institutions in Rajasthan, India. Annals of the Association of American Geographers, 99(1), pp.118-137.

19. Blakeney, M., 2009. Intellectual property rights and food security. Cabi.

20. Bouma, J. and Scott, C. 2006. The possibilities for dryland crop yield improvement in India's semi-arid regions: Observations from the field. Comprehensive Assessment Discussion Paper No. 3. Comprehensive Assessment Secretariat, IWMI, Hyderabad, India.

21. Bouma, J., van Soest, D. and Bulte, E. 2007. How sustainable is participatory watershed development in India? Agricultural Economics, 36, 13-22. 
22. Boxall, A.B., Rudd, M.A., Brooks, B.W., Caldwell, D.J., Choi, K., Hickmann, S., Innes, E., Ostapyk, K., Staveley, J.P., Verslycke, T. and Ankley, G.T., 2012. Pharmaceuticals and personal care products in the environment: what are the big questions?. Environmental health perspectives, 120(9), pp.12211229.

23. Brown, L.E., Mitchell, G., Holden, J., Folkard, A., Wright, N., Beharry-Borg, N., Berry, G., Brierley, B., Chapman, P., Clarke, S.J. and Cotton, L., 2010. Priority water research questions as determined by UK practitioners and policy makers. Science of the Total Environment, 409(2), pp.256-266.

24. Cassman K.G. and Grassini P. 2020. A global perspective on sustainable intensification research. Nature Sustainability, 3 pp.262-268.

25. Chaudhari, V. R., and Mishra, A. 2016. Multilevel policy responses to mainstream climate adaptation through watershed development in rainfed farming systems of India. Climate and Development, $8(4)$ pp.324-335.

26. Chava and Shah. 2012. Community-run Centres Improve Nutrition For Women and Children. Andhra Pradesh Rural Poverty Reduction Project. Innovations in Development 2012(6). The World Bank and Ministry of Finance, Department of Economic Affairs, Government of India

27. Chera, M. (2017). Transforming Millets: Strategies and Struggles in Changing Taste in Madurai. Food, Culture \& Society, 20(2), pp.303-324.

28. Chhotray, V. 2011. The Anti-Politics Machine in India: depoliticisation through local institution building for participatory watershed development. Journal of Development Studies 43(6), pp. 1037 1056.

29. Choudhury, S., Shankar, B., Aleksandrowicz, L., Tak, M., Green, R., Harris, F., Scheelbeek, P. and Dangour, A., 2020. What underlies inadequate and unequal fruit and vegetable consumption in India? An exploratory analysis. Global Food Security, 24, p.100332.

30. Chowdhury A., Hambly Odame H., Thompson S. and Hauser M. 2015. Enhancing farmers' capacity for botanical pesticide innovation through video-mediated learning in Bangladesh, International Journal of Agricultural Sustainability, 13:4, pp. 326-349.

31. Cole S.A. and Fernando A.N. 2012. The Value of Advice: Evidence from Mobile Phone-Based Agricultural Extension. Harvard Business School Working Paper 13-047, November 2012.

32. Cullet P. 2014. Groundwater law in India: Towards a framework ensuring equitable access and aquifer protection. Journal of Environmental Law 26(1):55-81.

33. D’Odorico, P., Bhattachan, A., Davis, K.F., Ravi, S. and Runyan, C.W., 2013. Global desertification: drivers and feedbacks. Advances in water resources, 51, pp.326-344.

34. Daftary, D. 2014. Watershed development and neoliberalism in India's drylands. J. Int. Development, 26(7), pp. 999-1010.

35. Dandekar, A. and Bhattacharya, S. 2017. Lives in Debt. Narratives of Agrarian Distress and Farmer Suicides. Economic and Political Weekly, L11:21, pp. 77-84.

36. Davis, K.F., Chhatre, A., Rao, N.D., Singh, D. and DeFries, R., 2019. Sensitivity of grain yields to historical climate variability in India. Environmental Research Letters, 14(6), p.064013.

37. DeFries, R., Chhatre, A., Davis, K.F., Dutta, A., Fanzo, J., Ghosh-Jerath, S., Myers, S., Rao, N.D. and Smith, M.R., 2018. Impact of historical changes in coarse cereals consumption in India on micronutrient intake and anemia prevalence. Food and nutrition bulletin, 39(3), pp.377-392.

38. Dey, C.J., Rego, A.I., Midwood, J.D. and Koops, M.A., 2020. A review and meta-analysis of collaborative research prioritization studies in ecology, biodiversity conservation and environmental science. Proceedings of the Royal Society B, 287(1923), p.20200012.

39. Dixon J, Gulliver A, Gibbon D (2001) Farming Systems and Poverty: Improving farmers livelihoods in a changing world. FAO and World Bank, Rome, Italy and Washington, DC, USA.

40. Dutta and Jhala 2014 Dutta, S. and Jhala, Y., 2014. Planning agriculture based on landuse responses of threatened semiarid grassland species in India. Biological conservation, 175, pp.129-139

41. FAO (2014) The Water-Energy-Food Nexus: A new approach in support of food security and sustainable agriculture. FAO, Rome, Italy.

42. FAO. 2019. Farmers Taking the Lead. Thirty Years of Famer Field Schools. Rome 
43. Farnworth C.R., Stirling, C., B. Sapkota, T., Jat, M.L., Misiko, M. and Attwood, S., 2017. Gender and inorganic nitrogen: what are the implications of moving towards a more balanced use of nitrogen fertilizer in the tropics?.International Journal of Agricultural Sustainability, 15(2), pp.136-152.

44. Foulds C., Bharucha, Z.P., Krupnik S., de Geus T., Suboticki I., Royston S. and Ryghaug M. 2019. An approach to identifying Social Sciences and Humanities energy research priorities for Horizon Europe: Working Group guidelines for systematic horizon scanning. Cambridge: Energy-SHIFTS.

45. Gajjar, S.P., Singh, C. and Deshpande, T., 2019. Tracing back to move ahead: a review of development pathways that constrain adaptation futures. Climate and Development, 11(3), pp.223-237.

46. Geist, H.J. and Lambin, E.F., 2004. Dynamic causal patterns of desertification. Bioscience, 54(9), pp.817-829.

47. Glendenning C., Babu S. and Asenso-Okyere K. 2010. Review of Agricultural Extension in India: Are Farmers' Information Needs Being Met? IPFRI Discussion Paper 01048. December 2010. IFPRI Eastern and Southern Africa Regional Office.

48. Govindaraj M., Rai K.N., Cherian B., Pfeiffer W.H., Kanatti A., and Shivade H. 2019. Breeding Biofortified Pearl Millet Varieties and Hybrids to Enhance Millet Markets for Human Nutrition. Agriculture, 9(5), pp. 106.

49. Gray, E. and Srinidhi, A. 2013. Watershed Development in India: Economic valuation and adaptation considerations. WRI Working Paper. World Resources Institute, Washington DC, USA.

50. Hegde G, Singh C, Kaur H (2018) Adaptation as Innovation - lessons from smallholder farmers in rainfed Karnataka. ASSAR Booklet, South Africa.

51. Herrero, M., Thornton, P.K., Power, B., Bogard, J.R., Remans R., Fritz S., Gerber J.S., Nelson, G., See, L., Waha, K., Watson, R.A., West, P.C., Samberg, L.H., van de Steeg, J., Stephenson, E., van Wijk, M. and Havlík, P. 2017. Farming and the geography of nutrient production for human use: a transdisciplinary analysis. Lancet Planet Health, 1, e33-42.

52. Hill, S., 1985. Redesigning the food system for sustainability. Alternatives: Global, Local, Political, 12(3).

53. Hines P., Yu L.H., Guy R.H., Brand A. and Papaluca-Amati M. 2019. Scanning the horizon: a systematic literature review of methodologies. BMJ Open, 9, e026764.

54. IAASTD 2009. Agriculture at a Crossroads: International Assessment of Agricultural Knowledge, Science and Technology for Development. Island Press: Washington D.C.

55. Indoria, A.K., Sharma, K.L., Reddy, K.S., Srinivasarao, C., Srinivas, K., Balloli, S.S., Osman, M., Pratibha, G. and Raju, N.S., 2018. Alternative sources of soil organic amendments for sustaining soil health and crop productivity in India-impacts, potential availability, constraints and future strategies. Current Science, 115(11), p. 2052.

56. Ingram, J.S., Wright, H.L., Foster, L., Aldred, T., Barling, D., Benton, T.G., Berryman, P.M., Bestwick, C.S., Bows-Larkin, A., Brocklehurst, T.F. and Buttriss, J., 2013. Priority research questions for the UK food system. Food Security, 5(5), pp.617-636.

57. Jha et al. 2019. Jha, S., Das, J., Sharma, A., Hazra, B. and Goyal, M.K., 2019. Probabilistic evaluation of vegetation drought likelihood and its implications to resilience across India. Global and planetary change, 176, pp.23-35.

58. Kale, E. 2017. Problematic uses and practices of farm ponds in Maharashtra. Econ. Polit. Weekly. LII 3, 20-22.

59. Kavia, Z.D. and Harsh, L.N. 1993. Proven Technology of Sand Dune Stabilization-A Step to Combat Desertification. In Proc. of National Seminar on Afforestation of Arid Lands, Institute of Arid Zone Forestry Research (IAZFR), Govt. of India, Jodhpur.

60. Kerr, J., 2002. Watershed development, environmental services, and poverty alleviation in India. World development, 30(8), pp.1387-1400.

61. Khadse, A. and Rosset, P.M., 2019. Zero Budget Natural Farming in India - from inception to institutionalization. Agroecology and Sustainable Food Systems, 43(7-8), pp. 848-871.

62. Khadse, A., Rosset, P.M., Morales, H. and Ferguson, B. G., 2017; Taking agroecology to scale: the Zero Budget Natural Farming peasant movement in Karnataka, India. The Journal of Peasant Studies, 45(1), pp. 192-219. 
63. Klein Goldewijk K., Beusen A., Doelman J and Stehfest E. 2017. Anthropogenic land use estimates for the Holocene - HYDE 3.2. Earth System Science Data 9(2), 927-953.

64. Krätli, S. 2015. Valuing variability: New perspectives on climate resilient drylands development. IIED: London. URL: http://pubs.iied.org/10128IIED.html

65. Kumar and Srivastava 2018 Kumar, S. and Srivastava, S. 2018. Biodiversity Conservation and Agricultural Intensification in India through Integration of IPR. In The Role of Intellectual Property Rights in Agriculture and Allied Sciences (pp. 87-120). Apple Academic Press.

66. Kumar V., Jain S.K. and Singh Y. 2010. Analysis of long-term rainfall trends in India. Hydrological Sciences Journal, 55(4), pp. 484-496.

67. Kumar, M., Reddy, K.S., Adake, R.V. and Rao, C.V.K.N., 2015. Solar powered micro-irrigation system for small holders of dryland agriculture in India. Agricultural Water Management, 158, pp.112119.

68. Kumar, R. 2019. Remaking Town and Hinterland: Reshaping Palates and Transforming Diets in Western Awadh, Uttar Pradesh. Conference presentation on panel 'Food Systems across Scales', Urban ARC, IIHS Bangalore. January 2019.

69. Kumar, R., 2019: India's Green Revolution and Beyond. Econ. Polit. Wkly., IIV, pp. 41- 48.

70. Law C., Fraser I. and Piracha M. 2020. Nutrition transition and changing food preferences in India. Journal of Agricultural Economics, https://doi.org/10.1111/1477-9552.12322

71. Mehta, L. (ed.) 2010. The limits to scarcity: Contesting the politics of allocation. London: Earthscan.

72. Mehta, L. 2001. The manufacture of popular perceptions of scarcity. Dams and water-related narratives in Gujarat, India. World Development, 29, 2025-2041.

73. Mehta, L. 2005. The politics and poetics of water: Naturalising water scarcity in western India. New Delhi: Orient Longman.

74. Milesi, C., Samanta, A., Hashimoto, H., Kumar, K.K., Ganguly, S., Thenkabail, P.S., Srivastava, A.N., Nemani, R.R. and Myneni, R.B., 2010. Decadal variations in NDVI and food production in India. Remote Sensing, 2(3), pp.758-776.

75. Minocha, S., Thomas, T. and Kurpad, A.V., 2018. Are 'fruits and vegetables' intake really what they seem in India?. European journal of clinical nutrition, 72(4), pp.603-608.

76. Mirzabaev A. and Wu J. et al. 2019. Desertification. Chapter 3, Intergovernmental Panel on Climate Change.

77. Morrison, K. D. (2016). From millets to rice (and back again?): Cuisine, cultivation, and health in southern India. A companion to South Asia in the past, 358-73.

78. Patel J.G., Murthy T.V.R., Singh T.S. and Panigraphy S. undated. Analysis of the distribution pattern of wetlands in India in relation to climate change. ISPRS Archives XXXVIII-8/W3 Workshop Proceedings: Impact of climate change on agriculture.

79. Pingali, P., Aiyar A., Abraham M. and Rahman A. 2019. Transforming Food Systems for a Rising India. Palgrave MacMillan.

80. Pradhyan, S. and Ruysenaar, S., 2014. Burning desires: untangling and interpreting 'pro-poor'biofuel policy processes in India and South Africa. Environment and Planning A, 46(2), pp.299-317.

81. Prakash, G. 2018. Review of the food processing supply chain literature: a UK, India bilateral context. Journal of Advances in Management Research, 15(4), pp. 457-479.

82. Prăvălie 2016. Drylands extent and environmental issues. A global approach. Earth Science Reviews, $161,259-278$.

83. Pray and Nagarajan 2009. Pearl Millet and Sorghum Improvement in India. IFPRI Discussion Paper 00919. IFPRI: Washington D.C.

84. Pretty, J, Sutherland WJ, Ashby J, et al. 2010. The top 100 questions of importance to the future of global agriculture. International Journal of Agricultural Sustainability, 8, pp.219-236.

85. Pretty, J. and Bharucha, Z.P., 2014. Sustainable intensification in agricultural systems. Annals of botany, 114(8), pp.1571-1596.

86. Pretty, J. and Bharucha, Z.P., 2018. Sustainable Intensification of Agriculture: Greening the World's Food Economy. Routledge. 
87. Pretty, J., Benton, T.G., Bharucha, Z.P., Dicks, L.V., Flora, C.B., Godfray, H.C.J., Goulson, D., Hartley, S., Lampkin, N., Morris, C. and Pierzynski, G., 2018. Global assessment of agricultural system redesign for sustainable intensification. Nature Sustainability, 1(8), pp.441-446.

88. Pretty, J., Toulmin, C. and Williams, S., 2011. Sustainable intensification in African agriculture. International journal of agricultural sustainability, 9(1), pp.5-24.

89. Pretty, J.N., 1997. The sustainable intensification of agriculture. In Natural resources forum (Vol. 21, No. 4, pp. 247-256). Oxford, UK: Blackwell Publishing Ltd.

90. Pullin A.S., Knight T. M., Watkinson A.R. 2009. Linking reductionist science and holistic policy using systematic reviews: unpacking environmental policy questions to construct an evidence-based framework. Journal of Applied Ecology, 46, pp. 970-975.

91. Rai, K. N., D. S. Murty, D. J. Andrews, and P. J. Bramel-Cox. 1999. Genetic enhancement of pearl millet and sorghum for the semi-arid tropics of Asia and Africa. Genome 42: 617-628.

92. Raina, R.S., 2006, August. Researching the drylands. In SEMINAR-NEW DELHI- (Vol. 564, p. 25).

93. Ramamoorthy, K., Lourduraj, A.C., Thiyagarajan, T.M., Sekhar, M.P. and Steware, B.A., 2004. Weeds and weed control in dryland agriculture-A review. Agricultural Reviews, 25(2), pp.79-99.

94. Rampal P. 2018. An analysis of protein consumption in India through plant and animal sources. Food and Nutrition Bulletin, 39(4), 564-580.

95. Rao A.S. 2011. Soil Health Issues in Rainfed Agriculture. Indian J Dryland Agri. Res \& Dev, 2(6), pp. $1-20$.

96. Rao, A.N., Singh, R.G., Mahajan, G. and Wani, S.P., 2018. Weed research issues, challenges, and opportunities in India. Crop Protection, p.104451.

97. Rao, C.S., Lal, R., Prasad, J.V., Gopinath, K.A., Singh, R., Jakkula, V.S., Sahrawat, K.L., Venkateswarlu, B., Sikka, A.K. and Virmani, S.M., 2015. Potential and challenges of rainfed farming in India. In Advances in agronomy (Vol. 133, pp. 113-181). Academic Press.

98. Ravindra, A. 2007. Regenerating lands and livelihoods. Harvard International Review. http://hir.harvard.edu/archives/1466

99. Rego T.J., Sahrawat K.L., Wani S.P. and Pardhasaradhi G. 2007. Widespread Deficiencies of Sulfur, Boron, and Zinc in Indian Semi-Arid Tropical Soils: On Farm Crop Responses. Journal of Plant Nutrition, 30, pp. 1583-1583.

100.Reynolds J., Stafford Smith D.M., Lambin, E., Turner II, B.L., Mortimore, M.J., Batterbury, S.P. J., Downing, T.E., Dowlatabadi, H., Fernández, R.J., Herrick, J.E., Huber-Sannwald, E., Jiang, H., Leemans, R., Lynam, T., Maestre, F. T., Ayarza, M. and Walker, B. 2007. Global Desertification: Building a Science for Dryland Development Science 316: 847-851.

101.Rockström, J. et al. Sustainable intensification of agriculture for human prosperity and global sustainability. Ambio 46, pp.4-17.

102.Rudd, M.A., Ankley, G.T., Boxall, A.B. and Brooks, B.W., 2014. International scientists' priorities for research on pharmaceutical and personal care products in the environment. Integrated environmental assessment and management, 10(4), pp.576-587.

103.Ryan, J.G. and Spencer, D.C., 2001. Future challenges and opportunities for agricultural $R \& D$ in the semi-arid tropics. International Crops Research Institute for the Semi-Arid Tropics, Hyderabad, India.

104.Sajesh, V. K., and A. Suresh, 2016: Public-Sector Agricultural Extension in India: A Note. Review of Agrarian Studies 6(1) 1-8.

105.Samuel, A., Joy, K. A., Paranjape, S., Peddi, S., Adagale, R., Deshpande, P. and Kulkarni, S. 2007. Watershed Development in Maharashtra: Present Scenario and Issues for Restructuring. Society for Promoting Participative Ecosystem Management (SOPPECOM): Pune. URL: http://www.forward.org.in/pdf/Maharashtra watershedReport2007.pdf

106. Samuel, A., Joy, K.J., Paranjape, S., Kale, E., Adagale, R. and Pomane, R. 2009. Watershed Development in Maharashtra: A Large Scale Rapid Assessment. SOPPECOM: Pune. URL: http://www.forward.org.in/publications.htm

107.Schneider, UA \& Smith, P 2009, 'Energy intensities and greenhouse gas emission mitigation in global agriculture', Energy Efficiency, 2(2), pp. 195-206.

108. Shankar, P.V., Kulkarni, H. and Krishnan, S., 2011. India's groundwater challenge and the way forward. Economic and Political Weekly, pp.37-45.

109. Shetty P. 2012. Public health: India's diabetes time bomb. Nature 485, pp. S14-S16. 
110.Singh 2018 Is Participatory Watershed Development Building Local Adaptive Capacity? Findings from a case study in Rajasthan, India. Environment and Development, DOI: 10.1016/j.envdev.2017.11.004

111.Sietz, D., 2011. Dryland vulnerability: typical patterns and dynamics in support of vulnerability reduction efforts (Doctoral dissertation, Universitätsbibliothek der Universität Potsdam).

112.Sietz, D., Ordoñez, J.C., Kok, M.T.J., Janssen, P., Hilderink, H.B., Tittonell, P. and Van Dijk, H., 2017. Nested archetypes of vulnerability in African drylands: where lies potential for sustainable agricultural intensification?. Environmental Research Letters, 12(9), p.095006.

113. Singh C. 2018. Is participatory watershed development building local adaptive capacity? Findings from a case study in Rajasthan, India. Environmental Development, 25, pp. 43-58.

114.Singh, C., 2019. Of borewells and bicycles: the gendered nature of water access and its implications on local adaptive capacity. En-gendering Climate Change: Learnings from South Asia. Routledge, A. Hans, N. Rao, A. Prakash, and A. Patel, Eds., Routledge, New Delhi, India.

115.Singh, C., A. Rahman, A. Srinivas, and A. Bazaz, 2018: Risks and responses in rural India: Implications for local climate change adaptation action. Clim. Risk Manag., 21, 52-68, doi:10.1016/j.crm.2018.06.001.

116.Singh, C., D. Solomon, R. Bendapudi, B. Kuchimanchi, S. Iyer, and A. Bazaz, 2019: What shapes vulnerability and risk management in semi-arid India? Moving towards an agenda of sustainable adaptation. Environmental Development, 30, 35-50, doi:10.1016/j.envdev.2019.04.007.

117.Solomon, D., Rao, N., 2018. Wells and Wellbeing: gender dimensions of groundwater dependence in South India. Econ. Pol. Wkly. 53, 38-45.

118.Srinivasa Rao C., Lal R., Prasad J.V.N.S., Gopinath K.A., Singh R., Jakkula V.S., Sahrawat K.L., Venkateswarlu B., Sikka A.K., Virmani S.M. 2015. Potential and Challenges of Rainfed Farming in India. In Sparks D.L. (ed.). Advances in Agronomy. pp. 113-181.

119.Srinivasa Rao C., Vittal K.P.R., Venkateswarlu B., Wani S.P., Sahrawat K.L., Marimuthu S., and Kundu S. 2009. Carbon Stocks in Different Soil Types under Diverse Rainfed Production Systems in Tropical India. Communications in Soil Science and Plant Science 40(15), pp. 2338-2356.

120.Steinke, J., van Etten, J., Müller, A., Ortiz-Crespo, B., van de Gevel, J., Silvestri, S. and Priebe, J., 2020. Tapping the full potential of the digital revolution for agricultural extension: an emerging innovation agenda. International Journal of Agricultural Sustainability, pp.1-17.

121.Sutherland, W.J., Broad, S., Butchart, S.H., Clarke, S.J., Collins, A.M., Dicks, L.V., Doran, H., Esmail, N., Fleishman, E., Frost, N. and Gaston, K.J., 2019b. A horizon scan of emerging issues for global conservation in 2019. Trends in ecology \& evolution, 34(1), pp.83-94.

122.Sutherland, W.J., Butchart, S.H., Connor, B., Culshaw, C., Dicks, L.V., Dinsdale, J., Doran, H., Entwistle, A.C., Fleishman, E., Gibbons, D.W. and Jiang, Z., 2018. A 2018 horizon scan of emerging issues for global conservation and biological diversity. Trends in Ecology \& Evolution, 33(1), pp.4758.

123. Sutherland, W.J., Fleishman, E., Clout, M., Gibbons, D.W., Lickorish, F., Peck, L.S., Pretty, J., Spalding, M. and Ockendon, N., 2019a. Ten years on: a review of the first global conservation horizon scan. Trends in ecology \& evolution, 34(2), pp.139-153.

124.Sutherland, W.J., Fleishman, E., Mascia M.B., Pretty, J. and Rudd M. A. 2011. Methods for collaboratively identifying research priorities and emerging issues in science and policy. Methods in Ecology and Evolution, 2, pp. 238-247.

125.Tanwar S.P.S., Bhati T.K., Singh A., Patidar M., Mathur B.K., Kumar P. and Yadav O.P. 2018. Rainfed integrated farming systems in arid zone in India: Resilience unmatched. Indian Journal of Agronomy, 63(4), pp. 403-414.

126.UNEP 2018. 'Andhra Pradesh to become India's first Zero Budget Natural Farming state'. Press Release, $2^{\text {nd }}$ June 2018. URL: https://www.unenvironment.org/news-and-stories/press-release/andhrapradesh-become-indias-first-zero-budget-natural-farming-state.

127. Valbuena, D., Erenstein, O., Homann-Kee Tui, S., Abdoulaye, T., Claessens, L., Duncan, A.J., Gérard, B., Rufino, M.C., Teufel, N., van Rooyen, A., van Wijk, M.T., 2012. Conservation agriculture in mixed crop-livestock systems: Scoping crop residue trade-offs in Sub-Saharan Africa and South Asia. Field Crops Research 132, 175-184. 
128. Van den Berg H. and Jiggins J. 2007. Investing in farmers - the impacts of farmer field schools in relation to integrated pest management. World Development 35, 663-686.

129.van der Esch, S., ten Brink, B., Stehfest, E., Bakkenes, M., Sewell, A., Bouwman, A., Meijer, J., Westhoek, H., van den Berg, M., van den Born, G.J. and Doelman, J., 2017. Exploring future changes in land use and land condition and the impacts on food, water, climate change and biodiversity: Scenarios for the UNCCD Global Land Outlook.

130. Varghese N., Dogra A., Sarker A. and Hassan A.A. 2019. The Lentil Economy in India. In Singh, M. (ed.) Lentils: Potential Resources for Enhancing Genetic Gains. pp. 203-219.

131.Varma, P., John J. and Bhatt A. 2019. Impact of Minimum Support Price Policy and National Food Security Mission on the Production of Pulses in India. Indian Institute of Management, Ahmedabad.

132.Varshney, R.K., Mohan, S.M., Gaur, P.M., Gangarao, N.V.P.R., Pandey, M.K., Bohra, A., Sawargaonkar, S.L., Chitikineni, A., Kimurto, P.K., Janila, P. and Saxena, K.B., 2013. Achievements and prospects of genomics-assisted breeding in three legume crops of the semi-arid tropics. Biotechnology advances, 31(8), pp.1120-1134.

133.Weltin, M., Zasada, I., Piorr, A., Debolini, M., Geniaux, G., Perez, O.M., Scherer, L., Marco, L.T. and Schulp, C.J., 2018. Conceptualising fields of action for sustainable intensification-A systematic literature review and application to regional case studies. Agriculture, ecosystems \& environment, 257, pp.68-80.

134. White R.P. and Nackoney J. 2003. Drylands, People, and Ecosystem Goods and Services. A Webbased Geospatial Analysis. World Resources Institute, Washington D.C.

135.Willer, H., Bernhard S., Jan T., Laura K. and Lernoud J. (eds.) 2020. The World of Organic Agriculture. Statistics and Emerging Trends 2020. Research Institute of Organic Agriculture (FiBL), Frick, and IFOAM - Organics International, Bonn.

136. Yadav, S.S. and Lal, R., 2018. Vulnerability of women to climate change in arid and semi-arid regions: The case of India and South Asia. Journal of Arid Environments, 149, pp.4-17.

137.Zoundji, G.C., Okry, F., Vodouhê, S.D. and Bentley, J.W., 2018. Towards sustainable vegetable growing with farmer learning videos in Benin. International journal of agricultural sustainability, 16(1), pp.54-63. 